\title{
Minireview
}

\section{Which biomarker predicts benefit from EGFR-TKI treatment for patients with lung cancer?}

\author{
H Uramoto' and T Mitsudomi*,2 \\ 'Cancer Chemotherapy Center, University of Occupational and Environmental Health, Japan. Yahatanishi-ku Kitakyushu 807-8555, Japan; ²Department \\ of Thoracic Surgery, Aichi Cancer Center Hospital, I-I, Kanokoden, Chikusa-ku, Nagoya 464-8681, Japan
}

\begin{abstract}
Subsets of patients with non-small cell lung cancer respond remarkably well to small molecule tyrosine kinase inhibitors (TKI) specific for epidermal growth factor receptor (EGFR) such as gefitinib or erlotinib. In 2004, it was found that EGFR mutations occurring in the kinase domain are strongly associated with EGFR-TKI sensitivity. However, subsequent studies revealed that this relationship was not perfect and various predictive markers have been reported. These include EGFR gene copy numbers, status of ligands for EGFR, changes in other HER family genes or molecules downstream to EGFR including KRAS or AKT. In this review, we would like to review current knowledge of predictive factors for EGFR-TKI. As all but one phase III trials failed to show a survival advantage of the treatment arm involving EGFR-TKls, it is necessary to select patients by these biomarkers in future clinical trials. Through these efforts, it would be possible to individualise EGFR-TKI treatment for patients suffering from lung cancer.

British Journal of Cancer (2007) 96, 857-863. doi: I0.1038/sj.bjc.6603665 www.bjcancer.com

Published online 27 February 2007

(C) 2007 Cancer Research UK
\end{abstract}

Keywords: gefitinib; erlotinib; biomarker; clinical trials; individualized therapy

Lung cancer is the leading cause of cancer-related mortality in Japan as well as in Western countries. The high mortality is mainly because of early development of systemic disease and resistance to currently available treatment strategies. Although various chemotherapeutic agents were developed in the late 1980s and 1990s, platinum doublet therapy seems to reach a therapeutic plateau with an objective response rate of $30-40 \%$ and a median survival time (MST) of 8-10 months for patients with stage IIIB or IV disease.

To circumvent this situation, a new class of drugs that specifically targets certain molecular pathways leading to cancer phenotypes is being actively developed. The epidermal growth factor receptor (EGFR) pathways have been investigated as a potential target for cancer therapy because EGFR overexpression is frequently observed and associated with a poor prognosis or resistance to chemotherapy. Antibodies directed against the extracellular domain of EGFR (such as cetuximab, matuzumab and panitumab) and small-molecule tyrosine kinase inhibitors (TKIs) that target the kinase domain (such as gefitinib and erlotinib) are in clinical use or in a late developmental stage.

In the phase II trail of gefitinib and early clinical development, subgroups of patients who are of Asian origin, female sex, adenocarcinoma and no history of smoking have been significantly associated with a favourable response to TKIs (Fukuoka et al, 2003; Kris et al, 2003; Miller et al, 2004). An analysis of 1974 patients taken from the literature (Mitsudomi et al, 2006) indicated that the TKI response is significantly dependent on ethnicity (Caucasian

*Correspondence: Dr T Mitsudomi; E-mail: mitsudom@aichi-cc.jp Received 17 October 2006; revised 31 January 2007; accepted 5 February 2007; published online 27 February 2007
$10 \%$ vs East Asians 33\%), gender (male 13\% vs female 33\%), smoking history (never smoker $40 \%$ vs current/former smokers $11 \%$ ), and histologic type (adenocarcinoma 29\% vs nonadenocarcinoma 5\%). However, it was not possible to predict gefitinib sensitivity by levels of EGFR overexpression, determined by immunohistochemistry or immunoblotting. The factors that determine gefitinib sensitivity have long been an enigma.

\section{EGFR MUTATIONS}

In 2004, it was found that a subset of pulmonary adenocarcinoma has somatic, activating mutations of the EGFR gene (Lynch et al, 2004; Paez et al, 2004; Pao et al, 2004). Following these initial reports, various groups confirmed and extended the findings that EGFR mutations are found in the first four exons of the tyrosine kinase (TK) domain of the EGFR gene and about $90 \%$ of these EGFR mutations are either short, in-frame deletions in exon 19 or point mutations that result in a substitution of arginine for leucine at amino acid 858 (L858R). EGFR mutations were predominantly found in female subjects, nonsmokers, adenocarcinomas, and Japanese patients (for review, see Mitsudomi et al, 2006). These patient characteristics precisely coincide with those with a high response rate to EGFR-TKIs described above. Of particular interest, EGFR mutation is the first molecular abnormality that is more frequent in nonsmoking patients with non-small cell lung cancer (NSCLC). However, this does not necessarily mean that smoking has a protective effect for EGFR mutations. Our casecontrol study revealed that lung cancers harbouring EGFR mutation appear to occur independent of tobacco smoking, whereas lung cancers without EGFR mutations are very much dependent on smoking dose (Matsuo et al, 2007). Apparent inverse 
relationship between smoking and EGFR mutations was thus due to dilutional effect of EGFR-mutated tumours by EGFR nonmutated tumours (Matsuo et al, 2007).

When EGFR mutations were first reported, the most exciting finding was that lung cancer harbouring this genetic alteration showed a striking response to EGFR-TKIs (Lynch et al, 2004; Paez et al, 2004; Pao et al, 2004). According to the data for 1170 patients, more than $70 \%$ of NSCLCs with EGFR mutations respond to EGFR-TKIs, whereas $10 \%$ of tumours without EGFR mutations do so (Table 1). Furthermore, several investigators have reported that patients with EGFR mutations have a significantly longer survival than those with wild-type EGFR when treated with EGFR-TKIs (Table 1). However, data on predictors for survival are controversial. Some investigators claim that EGFR mutations are prognostic rather than predictive, because subset analysis of TRIBUTE or INTACT trials (comparing platinum chemotherapy with chemotherapy plus EGFR-TKI) indicated that patients with lung cancer having EGFR mutations did better even in patients treated only with chemotherapy (Bell et al, 2005; Eberhard et al, 2005). However, EGFR mutations was not a significant prognostic factor in an initial two large retrospective studies in surgically treated patients without gefitinib treatment (Kosaka et al, 2004; Shigematsu et al, 2005), although Shigematsu et al (2005) reported that patients with exon 19 deletion have significantly shorter survival than those with L858R, but this is not confirmed by other investigators so far. These results clearly show that EGFR mutations are important in determining EGFR-TKI sensitivity, although not perfect. High response rate in patients with EGFR mutations to gefitinib was confirmed in the recently published prospective phase II study (Inoue et al, 2006 and Table 1).

We first reported that response rate of gefitinib is higher for patients with deletional EGFR mutations than for those with other types of mutations, predominantly L858R (Mitsudomi et al, 2005) and others extended this observation by demonstrating survival difference between them (Jackman et al, 2006; Riely et al, 2006). On the other hand, one of the insertion mutation (D770insNPG) in exon 20 of the EGFR gene has been shown to be associated with in vitro resistance to erlotinib (Greulich et al, 2005). In this study, G719S of exon 18 showed intermediate sensitivity, suggesting the mutation-specific treatment strategy for patient care.

Two groups of researchers have recently developed transgenic mice that express either exon 19 deletion mutant or the L858R mutant in type II pneumocytes under the control of doxycycline (Ji et al, 2006; Politi et al, 2006). Expression of either EGFR mutant leads to the development of adenocarcinoma similar to human bronchioloalveolar cell carcinoma and withdrawal of doxycycline to reduce expression of transgene or erlotinib treatment resulted in tumour regression. Thus, these experiments showed that persistent EGFR signalling is required for tumour maintenance in human lung adenocarcinomas expressing EGFR mutants.

\section{EGFR GENE COPY NUMBER}

Cappuzzo et al (2004) reported that increase in EGFR gene copy number, as determined by fluorescence in situ hybridisation, is more predictive of the patient survival after gefitinib treatment than EGFR mutations (Cappuzzo et al, 2005a). However, this report does not necessarily refute the role of EGFR mutations as a predictive factor because EGFR mutations only failed to significantly affect overall survival $(P=0.09)$, whereas EGFR mutations were predictive of response rate and time to progression (Cappuzzo et al, 2005a). However, it should be noted that their definition of increased gene copy number included both gene amplification and high polysomy (more than $40 \%$ of tumour cells have more than four copies of the EGFR gene). It is biologically unclear whether high polysomy indicates the activation of the EGFR gene, resulting in effects similar to those caused by gene amplification. Tsao et al (2005) reported that increased EGFR gene copy number is most predictive of a longer survival in patients who received erlotinib in a phase III clinical trial (BR.21) that compared erlotinib with best supportive care. They concluded that the detection of EGFR mutations is not necessary in selecting patients who will benefit from erlotinib therapy (Tsao et al, 2005). Recently it was reported that EGFR gene copy number but not gene mutation was the predictor of clinical benefit from gefitinib in ISEL, a similar randomised trial comparing gefitinib with placebo (Hirsch et al, 2006).

However, many investigators refute this point. Han et al (2006) recently reported that $E G F R$ mutation and high gene copy number were associated with better objective response in univariate analysis. Only gefitinib-sensitive EGFR mutation was independently predictive of both response and survival in multivariate analysis. Furthermore, Tsao et al (2005) report that 53\% of the EGFR mutations they found were novel variant mutations, of which $92 \%$ were $\mathrm{C} / \mathrm{G} \rightarrow \mathrm{T} / \mathrm{A}$ or $\mathrm{A} / \mathrm{T} \rightarrow \mathrm{G} / \mathrm{C}$ transitions. Marchetti et al (2006) suggested that at least some of these mutations could be artifactual if Tsao et al (2005) used small amount of DNA from paraffin-embedded tissues. Tsao et al(2005) responded to this comment by stating that even when the mutation analysis was confined to patients with exon 19 deletion and L858R, overall results did not change, confirming no association of response and survival for mutations in the BR.21 trial (Tsao et al, 2005). In general, tumours with EGFR mutations tend to have gene amplification. Mutation and amplification are probably both important in determining TKI sensitivity. To resolve this controversy, both EGFR mutations and amplification should be determined prospectively in future clinical trials. These results are also summarised in Table 1.

\section{OTHER MOLECULAR PARAMETERS}

\section{Ligands}

Using cDNA microarray, increased expression of amphiregulin or TGF- $\alpha$, known to be the ligands for EGFR, is related with poor response to gefitinib (Kakiuchi et al, 2004). Recently, it was reported that heregulin, ligand for HER3, expression correlates with gefitinib insensitivity (Zhou et al, 2006). The ADAMs (a disintegrin and metalloproteases), zinc-dependent membraneassociated proteases, control the cleavage of most EGF-related ligands. Zhou et al (2006) also showed that ADAM17 protein is upregulated in NSCLC and correlated with heregulin-mediated HER3 activation, leading to gefitinib insensitivity

\section{Receptors}

In addition to EGFR gene copy numbers, Cappuzzo et al (2005c) reported that increased HER2 gene copy number is associated with response to gefitinib therapy in EGFR-mutated NSCLC. However, the same group reported that genomic gain for HER3 is not a marker for response or resistance to TKI therapy in advanced NSCLC patients (Cappuzzo et al, 2005b). It is also reported that cancer cells having HER2 mutations, present in a very small fraction of NSCLC, are insensitive to EGFR-TKI, but remain sensitive to HER2-targeted therapies (Wang et al, 2006).

\section{Downstream molecules}

Pao et al (2005b) first reported that lung cancers with KRAS mutations are resistant to EGFR-TKIs. None of the nine tumours with KRAS mutations responded to EGFR-TKIs (Pao et al, 2005b). However, Miller et al (2006) showed that in their study of adenocarcinoma with bronchioloalveolar cell feature treated with erlotinib, some of the tumours with KRAS mutations showed minor tumour shrinkage, although response rate of lung cancer 
Table I Effect of mutations and copy number of the EGFR gene on clinical outcome in patients treated with EGFR-TKls

\begin{tabular}{|c|c|c|c|c|c|c|c|c|c|}
\hline \multirow[b]{3}{*}{ Investigator } & \multirow[b]{3}{*}{ Source } & \multirow[b]{3}{*}{ TKI } & \multirow[b]{3}{*}{$\mathbf{N}$} & \multicolumn{6}{|c|}{ Tumour response } \\
\hline & & & & \multicolumn{2}{|c|}{ Mut } & \multicolumn{2}{|c|}{ Wt } & \multicolumn{2}{|c|}{$\mathbf{R R}$} \\
\hline & & & & $\mathbf{R}$ & NR & $\mathbf{R} \mathbf{N}$ & VR M & Mut & $\mathbf{W t}$ \\
\hline \multicolumn{10}{|c|}{ Retrospective analyses of patients from a single institution } \\
\hline Paez & Science 2004 & G & 9 & 5 & 0 & 0 & 41 & 100 & 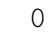 \\
\hline Lynch & NEJM 2004 & G & 16 & 8 & 0 & 1 & 71 & 100 & 13 \\
\hline Pao & PNAS 2004 & G & 18 & 7 & 0 & 3 & 81 & 100 & 27 \\
\hline Pao & PNAS 2004 & E & 17 & 5 & 0 & 2 & 101 & 100 & 17 \\
\hline Huang & JCO 2004 & G & 16 & 7 & I & 2 & 6 & 88 & 25 \\
\hline Tokumo & CCR 2005 & G & 21 & 8 & 1 & 2 & 10 & 89 & 17 \\
\hline Mitsudomi & JCO 2005 & G & 50 & 24 & 5 & 2 & 19 & 83 & 10 \\
\hline Han & JCO 2005 & G & 90 & 11 & 6 & 10 & 63 & 65 & 14 \\
\hline Kim & CCR 2005 & G & 27 & 6 & 0 & 2 & 191 & 100 & 10 \\
\hline Cortes-Funes & Ann Oncol 2005 & G & 78 & 6 & 4 & 6 & 62 & 60 & 9 \\
\hline Cappuzzo & NEJM 2005 & G & 89 & 8 & 7 & 4 & 70 & 53 & 5 \\
\hline Chou & CCR 2005 & G & 54 & 17 & 16 & 4 & 17 & 52 & 19 \\
\hline Taron & CCR 2005 & G & 65 & 16 & 1 & 6 & 42 & 94 & 13 \\
\hline Takano & JCO 2005 & G & 66 & 32 & 7 & 3 & 24 & 82 & 11 \\
\hline Zhang & Ann Oncol 2005 & G & 30 & 8 & 4 & 1 & 17 & 67 & 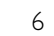 \\
\hline $\mathrm{Mu}$ & CCR 2005 & G & 22 & 7 & 3 & 0 & 12 & 70 & 0 \\
\hline Tomizawa & CCR 2005 & G & 22 & 12 & 0 & 4 & 61 & 100 & 40 \\
\hline Han & CCR 2006 & G & & & & & & & \\
\hline
\end{tabular}

Mutational status

Mut

Wt

Mut Wt

N Method R NR R NR High Low High Low

High Low

Retrospective analyses of patients enrolled in multiinstitutional clinical trials

$\begin{array}{lllllllll}\text { Bell JCO } & 2005 & \text { G } & 80 & 6 & 7 & 6 & 61 & 46\end{array}$

$\begin{array}{llllllllll}\text { Tsao } & \text { NEJM 2005 } & \text { E } & 100 & 3 & 16 & 6 & 75 & 16 & 7\end{array}$

Hirsch JCO 2006

$\begin{array}{lllllllll}32 & 6 & 10 & 3 & 113 & 38 & 3 & \text { Insufficient } & 19 t a\end{array}$

for survival analysis

$\begin{array}{ccc}25.1 & 14 & 0.15 \\ \text { NR } & 14 & 0.0053\end{array}$

$\begin{array}{lll}N 0.5 & 6.6 & <0.001\end{array}$

$\begin{array}{lll}47.3 & 11.9 & 0.008 \\ 13 & 4.9 & 0.02\end{array}$

$\begin{array}{llllll}9.9 & 2.7 & 0 & 13 & 4.9 & 0.02 \\ & 20.8 & 8.5 & 0.09\end{array}$

$14.5^{\mathrm{a}} 4^{\mathrm{a}} \quad 0.046$

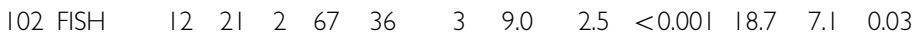

$\begin{array}{lll}N R & 9.9 & 0.001\end{array}$

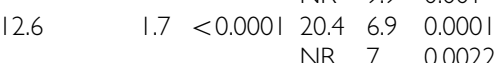

$\begin{array}{lllllllllll}66 & \text { qPCR } & 21 & 8 & 14 & 23 & 72 & 38 & 9.4 & 26.0 & 0.038\end{array}$

0.49

$\begin{array}{llllllllllllll}66 & \text { qPCR } & 10 & 21 & 4 & 31 & 32 & 11 & 3.6 & 1.9 & 0.21 & 12.3 & 8.4 & 0.49\end{array}$

Hirsch JCO 2005

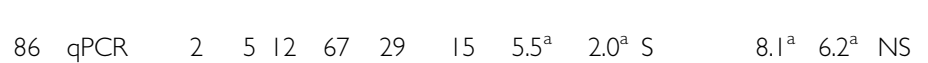

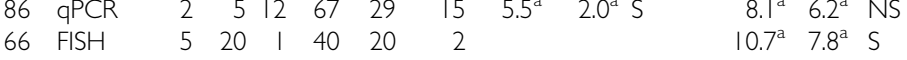

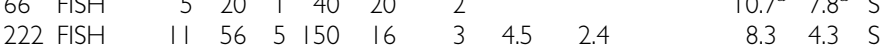

$\begin{array}{llllllllllllll}55 & \text { FISH } & 5 & 14 & 4 & 32 & 26 & \text { || } & 9.0 & 4.0 & 0.072 & \text { NR } & 8.0 & 0.042\end{array}$

Prospective study for EGFR mutation as a predictor of tumour response

$\begin{array}{lllllll}\text { Paz-Ares } & \text { ASCO } 2006 & \text { E } & 38 & 31 & 7 & 82 \\ \text { Oramoto } & \text { ASCO } 2006 & G & 27 & 20 & 7 & 74\end{array}$

$\begin{array}{llllllllll}\text { Okamoto } & \text { ASCO } 2006 & G & 27 & 20 & 7 & & & 74 & \\ \text { Sutani } & \text { ASCO } 2006 & \text { G } & 35 & 21 & 6 & 1 & 7 & 78 & 13\end{array}$

$\begin{array}{lllllllll}\text { Morikawa ASCO } 2006 \quad G \quad 47 & 21 & 13 & 2 & 11 & 62 & 15\end{array}$

$\begin{array}{lllllllll}\text { Morikawa } & \text { ASCO 2006 } & \text { G } & 47 & 21 & 13 & 2 & 11 & 62 \\ \text { Yoshida } & \text { JTO } 2007 & G & 21 & 19 & 2 & & 90\end{array}$

Totals $\quad 1170314 \quad 123 \quad 70663 \quad 72 \quad 10$

663

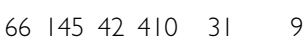

Abbreviations: E, erlotinib; EGFR, epidermal growth factor receptor; FISH, fluorescent in situ hybridisation; G, gefitinib; Mut, mutation; N, number of patients; NR, non-responder; NS, not significant; OS, Overall survival; qPCR, quantitative PCR; RR, response rate; TKI, tyrosine kinase inhibitor; TTP, time to progression; WT, wild-type; R, responder; S, significant. ${ }^{2}$ Read directly from graphs. 
with KRAS mutations was zero by RECIST. Thus, it is not possible to exclude patients with KRAS mutations from the list of patients with potential clinical benefit from EGFR-TKI therapy.

AKT is phosphorylated on EGFR activation, transmitting signals for cell survival. It is reported that patients with phospho AKTpositive tumours had a better response rate, disease control rate, and time to progression by gefitinib treatment (Cappuzzo et al, 2004). Expression of E-cadherin, a calcium-dependent adhesion molecule, has been related to sensitivity to gefitinib (Witta et al, 2006). These lines of evidence clearly indicate that comprehensive analyses of molecular biomarkers should be carried out in conjunction with clinical trials of EGFR inhibitors.

\section{RESISTANCE TO EGFR-TKI}

In contrast to the inherent resistance to gefitinib such as that by KRAS mutations described above, it is common for patients to show progressive disease after presenting with an initial good response. A secondary mutation resulting in threonine to methionine at codon $790(\mathrm{~T} 790 \mathrm{M})$ has been reported to be responsible for the acquired resistance (Kobayashi et al, 2005; Pao et al, 2005a). Crystal structure modelling has revealed that position T790 is located in the ATP-binding pocket of the catalytic region and appears to be critical for the binding of erlotinib and gefitinib. Substitution of the threonine at this codon with a bulkier residue, such as methionine, is thought to sterically hinder the binding of these two drugs. We recently reported that out of 14 patients who developed acquired resistance after initial good response, seven patients harboured additional T790M mutation (Kosaka et al, 2006). However, we were not able to find novel mutations related to this resistance, which is in good contrast with resistance in imatinib treatment for chronic myeloid leukaemia where more than 30 mutations of the $A B L$ gene have been reported. In tumours from patients not treated with TKI, T790M appears to be rare, approximately $0.5 \%$ (Toyooka et al, 2005). The possibility exists, however, that this second mutation might be present at a low frequency at the time of diagnosis and that tumour cells harbouring this mutation might be enriched over time during treatment with gefitinib (Inukai et al, 2006).

\section{TKIs AND CLINICAL TRIALS}

The addition of TKIs (gefitinib or erlotinib) did not yield a survival advantage over platinum doublet (carboplatin/paclitaxel or cisplatin/gemcitabine) in four randomised trials (INTACT I, II TALENT, and TRIBUTE). However, subgroup analysis of the TRIBUTE trial showed that the addition of erlotinib to carboplatin plus paclitaxel conferred an advantage in overall survival in patients who were never-smokers (MST 22.5 months vs 10.1 months; $P=0.01$ ) (Herbst et al, 2005).

In a randomised placebo-controlled trial to determine whether erlotinib prolonged survival in patients with NSCLC after the failure of chemotherapy (BR.21), erlotinib significantly prolonged survival, with an MST of 6.7 months vs 4.7 months (hazard ratio $0.70 ; P<0.001$ ) (Shepherd et al, 2005). In contrast, a similar placebo-controlled randomised trial using gefitinib (ISEL trial) failed to show an overall survival advantage in the gefitinib treatment group (MST of 5.6 months vs 5.1 months; $P=0.087$ ) (Thatcher et al, 2005). However, gefitinib prolonged survival in never-smokers (MST 8.9 months vs 6.1 months; $P=0.012$ ) as well as in Asian patients (MST 9.5 months vs 5.5 months; $P=0.010$ ) in preplanned subset analyses (Thatcher et al, 2005). Following these results, the US Food and Drug Administration limits the indication of gefitinib to cancer patients who are currently benefiting or have previously benefited from gefitinib treatment or are enrolled in clinical trials as of June 2005.

As has been described, EGFR-TKIs are not universally effective for lung cancer, but these drugs are effective in patients who have particular clinical or biological characteristics, for example, Asian, nonsmoking female patients with adenocarcinomas with EGFR mutations. The different outcomes of the BR.21 and ISEL trials are at least partly attributable to differences in the degree of dilution in the two trials of patients with the above-mentioned characteristics by those without such characteristics. Therefore, patients who would benefit from EGFR-TKI therapy should be concentrated in future clinical trials. Smoking history and EGFR mutations are good predictors of response in patients treated with EGFR-TKIs. Which of these two markers should we use in future clinical trials? In our exploratory subset analysis, tumour response was observed in 16 out of 19 patients with both EGFR mutations and no smoking history (Mitsudomi et al, 2005). Whereas a response was seen in one out of six never-smokers without EGFR mutations, a response was seen in eight out of 10 smokers with EGFR mutations (Mitsudomi et al, 2005). Therefore, our limited experience indicates that EGFR mutations may be superior to smoking history in the selection of patients who would benefit from TKI treatment and that smoking history is only a surrogate marker of EGFR mutation. Obviously, the detection of EGFR mutations requires laborious laboratory work. Hence, smoking history can be used in contexts in which EGFR gene testing is not readily available. In April 2004, IPASS (iressa pan-Asian study) was started. This is an open-labelled randomised phase III study comparing gefitinib monotherapy with cariboplatin/paclitaxel for previously untreated patients with adenocaricnoma who are neveror light smokers. The West Japan Thoracic Oncology Group, launched a phase III clinical trial comparing gefitinib monotherapy with cisplatin plus docetaxel in lung-cancer patients with $E G F R$. Primary end point is progression-free survival, to avoid confounding by possible crossover between two arms and the sample size is 200 patients with EGFR mutations. We also limit our mutation search to deletions in exon 19 and L858R, because it would be less laborious and these two are most reliable predictor for response or survival. In this way, the survival benefit of EGFRTKIs, especially gefitinib, should be demonstrated in future clinical trials in a defined subset of patients with lung cancer.

\section{LIFE-THREATENING INTERSTITIAL LUNG DISEASE}

In Japan, soon after the introduction of gefitinib, life-threatening interstitial lung disease or acute lung injury attributable to gefitinib became apparent. Recently published retrospective survey of 1976 Japanese patients showed prevalence and morality of ILD was 3.5 and $1.6 \%$, respectively (Ando et al, 2006). Gefitinibinduced ILD was significantly associated with male sex, a history of smoking, and coincidence of interstitial pneumonitis (odds ratios $3.10,4.79$, and 2.89, respectively) (Ando et al, 2006). Although it is not very clear whether the high incidence of ILD is common in East Asian countries, Chiu et al (2005) reported from Taiwan that geftinib-related interstitial pneumonia was clinically diagnosed in four cases $(5.8 \%)$ in 69 patients. Biomarkers including genetic polymorphisms that predict occurrence of ILD should be actively sought. The incidence of ILD by erlotinib appears similar in Japan. In a recent phase II trial of erlotinib conducted in Japan, possible ILD-like events were reported in four of 60 evaluable patients $(6.7 \%)$ (Tamura et al, 2006), whereas ILD was reported in three of 485 in BR. 21 (Shepherd et al, 2004).

\section{CONCLUSIONS}

Considering great complexity and redundancy of EGFR pathway, it is natural to assume that one cannot expect a sole determinant of clinical benefit of EGFR-TKIs. Figure 1 summarises current knowledge of molecular predictors for EGFR-TKI discussed above. The development of EGFR-TKIs and the discovery of EGFR gene mutations have provided a great opportunity for translation of 


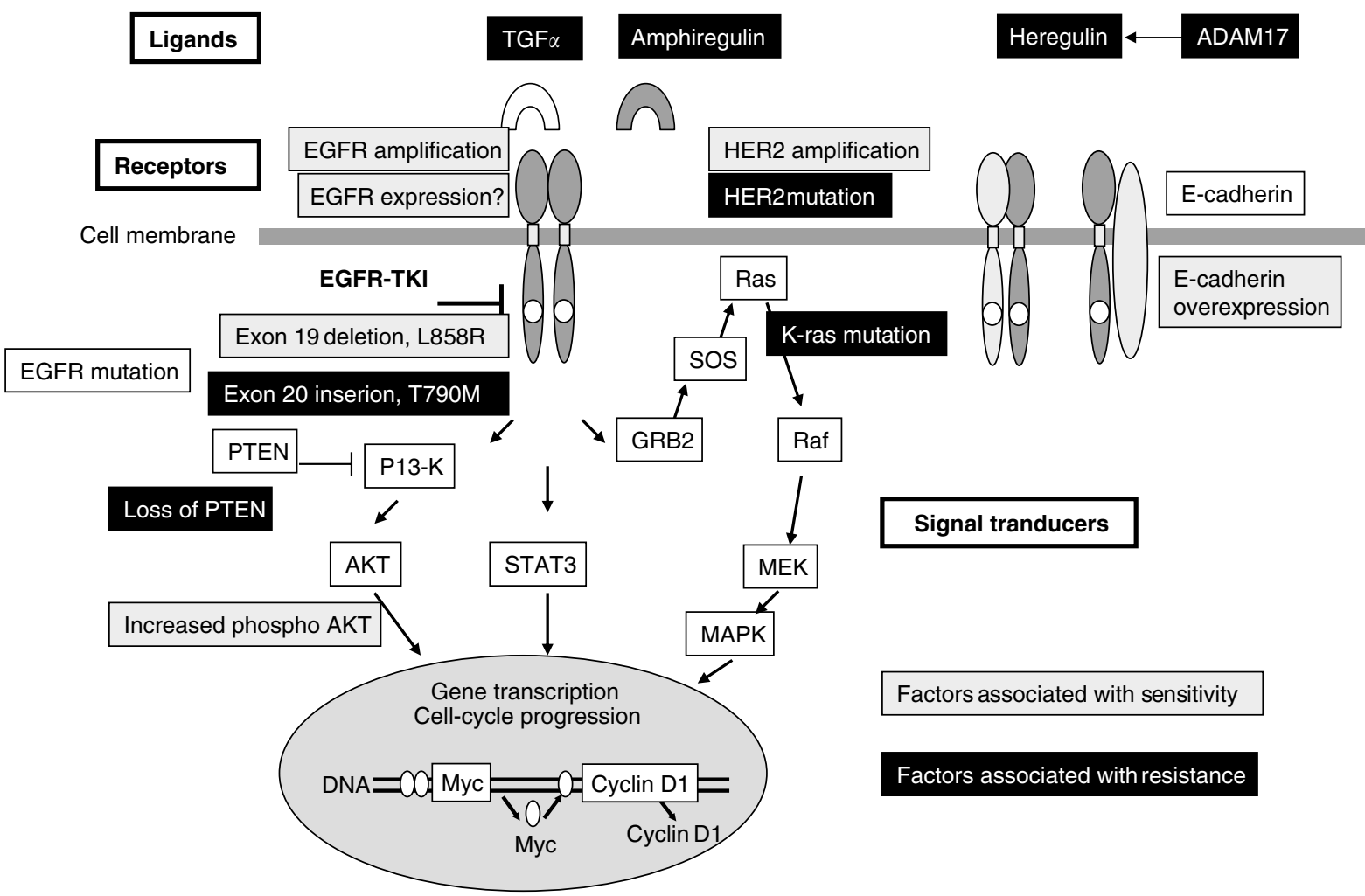

Figure I Potential molecular biomarkers to predict responsiveness for EGFR-TKI in EGFR signalling pathways. Sensitive and resistant markers are indicated by grey and black boxes, respectively.

cancer biology into clinics to realise individualised therapies for lung cancer. However, we should continue our effort to search for better biomarker(s) that is most clinically relevant. Particularly in Japan, risk of ILD and potential benefit of EGFR-TKI therapy should be well balanced.

\section{REFERENCES}

Ando M, Okamoto I, Yamamoto N, Takeda K, Tamura K, Seto T, Ariyoshi Y, Fukuoka M (2006) Predictive factors for interstitial lung disease, antitumor response, and survival in non-small-cell lung cancer patients treated with gefitinib. J Clin Oncol 24: 2549-2556

Bell DW, Lynch TJ, Haserlat SM, Harris PL, Okimoto RA, Brannigan BW, Sgroi DC, Muir B, Riemenschneider MJ, Iacona RB, Krebs AD, Johnson DH, Giaccone G, Herbst RS, Manegold C, Fukuoka M, Kris MG, Baselga J, Ochs JS, Haber DA (2005) Epidermal growth factor receptor mutations and gene amplification in non-small-cell lung cancer: molecular analysis of the IDEAL/INTACT gefitinib trials. J Clin Oncol 23: 8081-8092

Cappuzzo F, Hirsch FR, Rossi E, Bartolini S, Ceresoli GL, Bemis L, Haney J, Witta S, Danenberg K, Domenichini I, Ludovini V, Magrini E, Gregorc V, Dogilioni C, Sidoni A, Tonato M, Franklin WA, Crino L, Bunn Jr PA, Varella-Garcia M (2005a Epidermal growth factor receptor gene and protein and gefitinib sensitivity in non-small cell lung cancer. $J$ Natl Cancer Inst 97: 643-655

Cappuzzo F, Magrini E, Ceresoli GL, Bartolini S, Rossi E, Ludovini V, Gregorc V, Ligorio C, Cancellieri A, Damiani S, Spreafico A, Paties CT, Lombardo L, Calandri C, Bellezza G, Tonato M, Crino L (2004) Akt phosphorylation and gefitinib efficacy in patients with advanced nonsmall-cell lung cancer. J Natl Cancer Inst 96: 1133-1141

Cappuzzo F, Toschi L, Domenichini I, Bartolini S, Ceresoli GL, Rossi E, Ludovini V, Cancellieri A, Magrini E, Bemis L, Franklin WA, Crino L, Bunn PA, Jr, Hirsch FR, Varella-Garcia M (2005b) HER3 genomic gain and sensitivity to gefitinib in advanced non-small-cell lung cancer patients. Br J Cancer 93: $1334-1340$

\section{ACKNOWLEDGEMENTS}

This work was supported in part by a grant from the Clinical Research Foundation (2005) and from the Japan Society for the Promotion of Science (18390386).

Cappuzzo F, Varella-Garcia M, Shigematsu H, Domenichini I, Bartolini S, Ceresoli GL, Rossi E, Ludovini V, Gregorc V, Toschi L, Franklin WA, Crino L, Gazdar AF, Bunn PA, Jr, Hirsch FR (2005c) Increased HER2 gene copy number is associated with response to gefitinib therapy in epidermal growth factor receptor-positive non-small-cell lung cancer patients. J Clin Oncol 23: 5007-5018

Chiu CH, Tsai CM, Chen YM, Chiang SC, Liou JL, Perng RP (2005) Gefitinib is active in patients with brain metastases from non-small cell lung cancer and response is related to skin toxicity. Lung Cancer 47: 129-138 Eberhard DA, Johnson BE, Amler LC, Goddard AD, Heldens SL, Herbst RS, Ince WL, Janne PA, Januario T, Johnson DH, Klein P, Miller VA, Ostland MA, Ramies DA, Sebisanovic D, Stinson JA, Zhang YR, Seshagiri S, Hillan KJ (2005) Mutations in the epidermal growth factor receptor and in KRAS are predictive and prognostic indicators in patients with nonsmall-cell lung cancer treated with chemotherapy alone and in combination with erlotinib. J Clin Oncol 23: 5900-5909

Fukuoka M, Yano S, Giaccone G, Tamura T, Nakagawa K, Douillard JY, Nishiwaki Y, Vansteenkiste J, Kudoh S, Rischin D, Eek R, Horai T, Noda K, Takata I, Smit E, Averbuch S, Macleod A, Feyereislova A, Dong RP, Baselga J (2003) Multi-institutional randomized phase II trial of gefitinib for previously treated patients with advanced non-small-cell lung cancer. J Clin Oncol 21: 2237-2246

Greulich H, Chen T-H, Feng W, Janne PA, Alvarez JV, Bulmer SE, Zappaterra M, Frank DA, Hahn WC, Sellers WR, Meyerson M (2005) Oncogenic transformation by inhibitor-sensitive and resistant EGFR mutations. PLoS Med 2: e313 
Han SW, Kim TY, Jeon YK, Hwang PG, Im SA, Lee KH, Kim JH, Kim DW, Heo DS, Kim NK, Chung DH, Bang YJ (2006) Optimization of patient selection for gefitinib in non-small cell lung cancer by combined analysis of epidermal growth factor receptor mutation, K-ras mutation, and Akt phosphorylation. Clin Cancer Res 12: 2538-2544

Herbst RS, Prager D, Hermann R, Fehrenbacher L, Johnson BE, Sandler A, Kris MG, Tran HT, Klein P, Li X, Ramies D, Johnson DH, Miller VA (2005) TRIBUTE: a phase III trial of erlotinib hydrochloride (OSI-774) combined with carboplatin and paclitaxel chemotherapy in advanced non-small-cell lung cancer. J Clin Oncol 23: 5892 - 5899

Hirsch FR, Varella-Garcia M, Bunn PA, Jr, Franklin WA, Dziadziuszko R, Thatcher N, Chang A, Parikh P, Pereira JR, Ciuleanu T, von Pawel J, Watkins C, Flannery A, Ellison G, Donald E, Knight L, Parums D, Botwood N, Holloway B (2006) Molecular predictors of outcome with gefitinib in a phase III placebo-controlled study in advanced non-smallcell lung cancer. J Clin Oncol 24: 5034-5042

Inoue A, Suzuki T, Fukuhara T, Maemondo M, Kimura Y, Morikawa N, Watanabe H, Saijo Y, Nukiwa T (2006) Prospective phase II study of gefitinib for chemotherapy-naive patients with advanced non-small-cell lung cancer with epidermal growth factor receptor gene mutations. J Clin Oncol 24: $3340-3346$

Inukai M, Toyooka S, Ito S, Asano H, Ichihara S, Soh J, Suehisa H, Ouchida M, Aoe K, Aoe M, Kiura K, Shimizu N, Date H (2006) Presence of epidermal growth factor receptor gene T790M mutation as a minor clone in non-small cell lung cancer. Cancer Res 66: 7854-7858

Jackman DM, Yeap BY, Sequist LV, Lindeman N, Holmes AJ, Joshi VA, Bell DW, Huberman MS, Halmos B, Rabin MS, Haber DA, Lynch TJ, Meyerson M, Johnson BE, Janne PA (2006) Exon 19 deletion mutations of epidermal growth factor receptor are associated with prolonged survival in non-small cell lung cancer patients treated with gefitinib or erlotinib. Clin Cancer Res 12: 3908-3914

Ji H, Li D, Chen L, Shimamura T, Kobayashi S, McNamara K, Mahmood U, Mitchell A, Sun Y, Al-Hashem R, Chirieac LR, Padera R, Bronson RT, Kim W, Janne PA, Shapiro GI, Tenen D, Johnson BE, Weissleder R, Sharpless NE, Wong KK (2006) The impact of human EGFR kinase domain mutations on lung tumorigenesis and in vivo sensitivity to EGFR-targeted therapies. Cancer Cell 9: 485-495

Kakiuchi S, Daigo Y, Ishikawa N, Furukawa C, Tsunoda T, Yano S, Nakagawa K, Tsuruo T, Kohno N, Fukuoka M, Sone S, Nakamura Y (2004) Prediction of sensitivity of advanced non-small cell lung cancers to gefitinib (Iressa, ZD1839). Hum Mol Genet 13: 3029-3043

Kobayashi S, Boggon TJ, Dayaram T, Janne PA, Kocher O, Meyerson M, Johnson BE, Eck MJ, Tenen DG, Halmos B (2005) EGFR mutation and resistance of non-small-cell lung cancer to gefitinib. New Engl J Med 352: $786-792$

Kosaka T, Yatabe Y, Endoh H, Kuwano H, Takahashi T, Mitsudomi T (2004) Mutations of the epidermal growth factor receptor gene in lung cancer: biological and clinical implications. Cancer Res 64: $8919-8923$

Kosaka T, Yatabe Y, Endoh H, Yoshida K, Hida T, Tsuboi M, Tada H, Kuwano H, Mitsudomi T (2006) Analysis of epidermal growth factor receptor gene mutation in patients with non-small cell lung cancer and acquired resistance to gefitinib. Clin Cancer Res 12: 5764-5769

Kris MG, Natale RB, Herbst RS, Lynch Jr TJ, Prager D, Belani CP, Schiller JH, Kelly K, Spiridonidis H, Sandler A, Albain KS, Cella D, Wolf MK, Averbuch SD, Ochs JJ, Kay AC (2003) Efficacy of gefitinib, an inhibitor of the epidermal growth factor receptor tyrosine kinase, in symptomatic patients with non-small cell lung cancer: a randomized trial. JAMA 290: $2149-2158$

Lynch TJ, Bell DW, Sordella R, Gurubhagavatula S, Okimoto RA, Brannigan BW, Harris PL, Haserlat SM, Supko JG, Haluska FG, Louis DN, Christiani DC, Settleman J, Haber DA (2004) Activating mutations in the epidermal growth factor receptor underlying responsiveness of non-small-cell lung cancer to gefitinib. New Engl J Med 350: 2129-2139

Marchetti A, Felicioni L, Buttitta F (2006) Assessing EGFR mutations. New Engl J Med 354: 526-528, (author reply 526-528)

Matsuo K, Ito H, Yatabe Y, Hiraki A, Hirose K, Wakai K, Kosaka T, Suzuki T, Tajima K, Mitsudomi T (2007) Risk factors differ for non-small-cell lung cancers with and without EGFR mutation: assessment of smoking and sex by a case-control study in Japanese. Cancer Sci 98: 96-101

Miller VA, Kris MG, Shah N, Patel J, Azzoli C, Gomez J, Krug LM, Pao W, Rizvi N, Pizzo B, Tyson L, Venkatraman E, Ben-Porat L, Memoli N, Zakowski M, Rusch V, Heelan RT (2004) Bronchioloalveolar pathologic subtype and smoking history predict sensitivity to gefitinib in advanced non-small-cell lung cancer. J Clin Oncol 22: 1103-1109
Miller VA, Zakowski M, Riely GJ, Pao W, Ladanyi M, Tsao AS, Sandler A, Herbst R, Kris MG, Johnson DH (2006) EGFR mutation and copy number, EGFR protein expression and KRAS mutation as predictors of outcome with erlotinib in bronchioloalveolar cell carcinoma (BAC): Results of a prospective phase II trial. J Clin Oncol (meeting abstracts) 24: 7003

Mitsudomi T, Kosaka T, Yatabe Y (2006) Biological and clinical implications of EGFR mutations in lung cancer. Int J Clin Oncol 11: $190-198$

Mitsudomi T, Kosaka T, Endoh H, Horio Y, Hida T, Mori S, Hatooka S, Shinoda M, Takahashi T, Yatabe Y (2005) Mutations of the epidermal growth factor receptor gene predict prolonged survival after gefitinib treatment in patients with non-small-cell lung cancer with postoperative recurrence. J Clin Oncol 23: 2513-2520

Paez JG, Janne PA, Lee JC, Tracy S, Greulich H, Gabriel S, Herman P, Kaye FJ, Lindeman N, Boggon TJ, Naoki K, Sasaki H, Fujii Y, Eck MJ, Sellers WR, Johnson BE, Meyerson M (2004) EGFR mutations in lung cancer: correlation with clinical response to gefitinib therapy. Science 304: $1497-1500$

Pao W, Miller V, Zakowski M, Doherty J, Politi K, Sarkaria I, Singh B, Heelan R, Rusch V, Fulton L, Mardis E, Kupfer D, Wilson R, Kris M, Varmus H (2004) EGF receptor gene mutations are common in lung cancers from "never smokers" and are associated with sensitivity of tumors to gefitinib and erlotinib. Proc Natl Acad Sci USA 101: $13306-13311$

Pao W, Miller VA, Politi KA, Riely GJ, Somwar R, Zakowski MF, Kris MG, Varmus H (2005a) Acquired resistance of lung adenocarcinomas to gefitinib or erlotinib is associated with a second mutation in the EGFR kinase domain. PLoS Med 2: e73

Pao W, Wang TY, Riely GJ, Miller VA, Pan Q, Ladanyi M, Zakowski MF, Heelan RT, Kris MG, Varmus HE (2005b) KRAS mutations and primary resistance of lung adenocarcinomas to gefitinib or erlotinib. PLoS Med 2: e17

Politi K, Zakowski MF, Fan PD, Schonfeld EA, Pao W, Varmus HE (2006) Lung adenocarcinomas induced in mice by mutant EGF receptors found in human lung cancers respond to a tyrosine kinase inhibitor or to down-regulation of the receptors. Genes Dev 20: 1496-1510

Riely GJ, Pao W, Pham D, Li AR, Rizvi N, Venkatraman ES, Zakowski MF, Kris MG, Ladanyi M, Miller VA (2006) Clinical course of patients with non-small cell lung cancer and epidermal growth factor receptor exon 19 and exon 21 mutations treated with gefitinib or erlotinib. Clin Cancer Res 12: $839-844$

Shepherd FA, Pereira J, Ciuleanu TE, Tan EH, Hirsh V, Throngprasert S, Bezjak A, Tu D, Santabarbara P, Seymour L (2004) A randomized placebo-controlled trial of erlotinib in patients with advanced non-small cell lung cancer following failure of 1st line or 2nd line chemotherapy. Proc Am Soc Clin Oncol 22: 622 s.

Shepherd FA, Rodrigues Pereira J, Ciuleanu T, Tan EH, Hirsh V, Thongprasert S, Campos D, Maoleekoonpiroj S, Smylie M, Martins R, van Kooten M, Dediu M, Findlay B, Tu D, Johnston D, Bezjak A, Clark G, Santabarbara P, Seymour L (2005) Erlotinib in previously treated nonsmall-cell lung cancer. New Engl J Med 353: 123-132

Shigematsu H, Lin L, Takahashi T, Nomura M, Suzuki M, Wistuba II Fong KM, Lee H, Toyooka S, Shimizu N, Fujisawa T, Feng Z, Roth JA, Herz J, Minna JD, Gazdar AF (2005) Clinical and biological features associated with epidermal growth factor receptor gene mutations in lung cancers. I Natl Cancer Inst 97: 339-346

Tamura K, Nishiwaki Y, Tamura T, Nakagawa K, Matsui K, Watanabe K, Saijo N, Fukuoka M (2006 A phase II study of the HER1/EGFR tyrosine kinase inhibitor, erlotinib, in Japanese patients with non-small cell lung cancer previously treated with platinum-based therapy. Ann Oncol 17(supplement 9): ix 221-222

Thatcher N, Chang A, Parikh P (2005) Results of a phase III placebocontrolled study (ISEL) of gefitinib (IRESSA) plus best supportive care (BSC) in patients with advanced non-cmall-cell lung cancer (NSCLC) who had received 1 or 2 prior chemotherapy regimens. Proc Am Assoc Cancer Res 46(suppl): Abstract \# LB-6

Toyooka S, Kiura K, Mitsudomi T (2005) EGFR mutation and response of lung cancer to gefitinib. $N$ Engl J Med 352: 2136; author reply 2136

Tsao MS, Sakurada A, Cutz JC, Zhu CQ, Kamel-Reid S, Squire J, Lorimer I, Zhang T, Liu N, Daneshmand M, Marrano P, da Cunha Santos G, Lagarde A, Richardson F, Seymour L, Whitehead M, Ding K, Pater J, Shepherd FA (2005) Erlotinib in lung cancer - molecular and clinical predictors of outcome. New Engl J Med 353: 133 - 144 
Wang SE, Narasanna A, Perez-Torres M, Xiang B, Wu FY, Yang S, Carpenter G, Gazdar AF, Muthuswamy SK, Arteaga CL (2006) HER2 kinase domain mutation results in constitutive phosphorylation and activation of HER2 and EGFR and resistance to EGFR tyrosine kinase inhibitors. Cancer Cell 10: 25-38

Witta SE, Gemmill RM, Hirsch FR, Coldren CD, Hedman K, Ravdel L, Helfrich B, Dziadziuszko R, Chan DC, Sugita M, Chan Z, Baron A, Franklin W, Drabkin HA, Girard L, Gazdar AF, Minna JD, Bunn Jr PA
(2006) Restoring E-cadherin expression increases sensitivity to epidermal growth factor receptor inhibitors in lung cancer cell lines. Cancer Res 66: $944-950$

Zhou BB, Peyton M, He B, Liu C, Girard L, Caudler E, Lo Y, Baribaud F, Mikami I, Reguart N, Yang G, Li Y, Yao W, Vaddi K, Gazdar AF, Friedman SM, Jablons DM, Newton RC, Fridman JS, Minna JD, Scherle PA (2006) Targeting ADAM-mediated ligand cleavage to inhibit HER3 and EGFR pathways in non-small cell lung cancer. Cancer Cell 10: 39-50 